\title{
APPLICATION OF ALLO MESENCHYMAL STEM CELLS ON CHRONIC BURN WOUND: CASE SERIES REPORT
}

\author{
Aditya Wardhana ${ }^{1,2 *}$, Isabella Kurnia Liem², Lauda Feroniasanti², Dyah Juliana Pudjiti2, Fajar \\ Mujadid², Tera Kispa², Novialdi²
}

1. Universitas Indonesia, Department of Surgery, Division of Plastic Reconstructive and Aesthetic Surgery, RSUPN Cipto Mangunkusumo, Jakarta, Indonesia

2. Stem Cell Research Unit, Faculty of Medicine, University of Indonesia, Cipto Mangunkusumo National General Hospital, Jakarta, Indonesia

\begin{abstract}
Background : Severe burns are among the commonly occurring trauma with lethal outcome. One of the important aspects of severe burn therapy is to quickly achieve wound healing. Previous reports indicated that mesenchymal stem cells (MSCs) therapy contributes in facilitating better wound healing. In this report, we investigated the effects of MSCs derived from human bone marrow and umbilical cord on wound healing in patients with severe burns and its mechanism.
\end{abstract}

Method : We performed human bone marrow and human umbilical cord MSCs therapy on 3 severe burns patients. Two of the patients had inadequate donor to close raw surface with skin graft, whilst one patient had infected chronic burn wound which have failed to epithelialize despite repeated attempts of skin graft and wound care.

Result : We observed that MSCs therapy significantly accelerated wound healing. The effects after MSCs migrated into wound were decreased infiltration of inflammatory cells and faster epithelialization. .

Conclusion : This study suggests that MSCs therapy has positive effects in improving wound healing in severe burns patients. Data provided by this research may serve as theoretical basis for further study of MSCs application in burn wound therapy.

Keywords: bone marrow, umbilical cord, mesenchymal stem cell, burn wound healing

Latar Belakang: Luka bakar berat merupakan kasus yang sering ditemukan dan merupakan trauma yang letal. Prinsip penting pada terapi luka bakar berat adalah untuk mempercepat penyembuhan luka sedini mungkin, dan beberapa laporan kasus mengindikasikan bahwa terapi mesenchymal stem cell (MSC) dapat berkontribusi dalam memfasilitasi penyembuhan luka. Pada laporan kasus ini, kami menginvestigasi efek MSC sumsum tulang dan tali pusar manusia terhadap penyembuhan luka bakar pasien dan mekanismenya.

Metodologi: Kami melakukan terapi MSCs yang diperoleh dari sumsum tulang dan tali pusat manusia pada 3 pasien luka bakar berat. Dua pasien memiliki area donor yang minimal untuk penutupan defek menggunakan skin graft dan 1 pasien dengan luka bakar kronis terinfeksi yang selalu gagal epiteliasisasi dengan skin graft berulang dan perawatan luka. Kemudian dilakukan aplikasi hUC-MSCs pada pasien sebagai alternatif untuk penyembuhan luka yang lebih baik.

Hasil: Kami mengamati terjadinya percepatan penyembuhan luka yang signifikan pada terapi MSCs. Sel MSCs melakukan migrasi ke dalam luka dan menurunkan jumlah infiltrasi sel inflamasi, dan juga terjadi epitelialisasi yang lebih cepat dibandingkan kulit yang lain..

Kesimpulan: Studi ini menyarankan terapi MSCs karena dapat memperbaiki penyembuhan luka pada luka bakar berat. Selain itu, data ini dapat dijadikan dasar teori untuk aplikasi klinis MSCs pada luka bakar di masa depan.

Kata Kunci : bone marrow, umbilical cord, mesenchymal stem cell, burn wound healing 


\section{INTRODUCTION}

Severe burns are among the commonly occurring trauma with lethal outcome. One of the important aspects of severe burn therapy is to quickly achieve wound healing. Previous reports indicated that mesenchymal stem cells (MSCs) therapy contributes in facilitating better wound healing. In this report, we investigated the effects of MSCs derived from human bone marrow and umbilical cord on wound healing in patients with severe burns and its mechanism.

\section{CASE REPORT}

We performed human bone marrow and human umbilical cord MSCs therapy on 3 severe burns patients. Two of the patients had inadequate donor to close raw surface with skin graft, whilst one patient had infected chronic burn wound which have failed to epithelize despite repeated attempts of skin graft and wound care. The human umbilical cord- mesenchymal stem cell was applied to the patient for an alternative therapy to achieve wound closure.

Case 1: 51 years old female. She had infected chronic burn wound, she previously suffered tburn injury grade II and III about $35 \%$ total body surface area due to fire. In the span of 1 year she had repeated skin graft procedure and wound care, unfortunately the wound failed to achieve epithelialization. The wound was exudative and had secondary infection. We decided to try the application of mesenchymal stem cells therapy to the wound, and there was notable progress in reduced exudates and the epithelialization started to cover the raw surface.
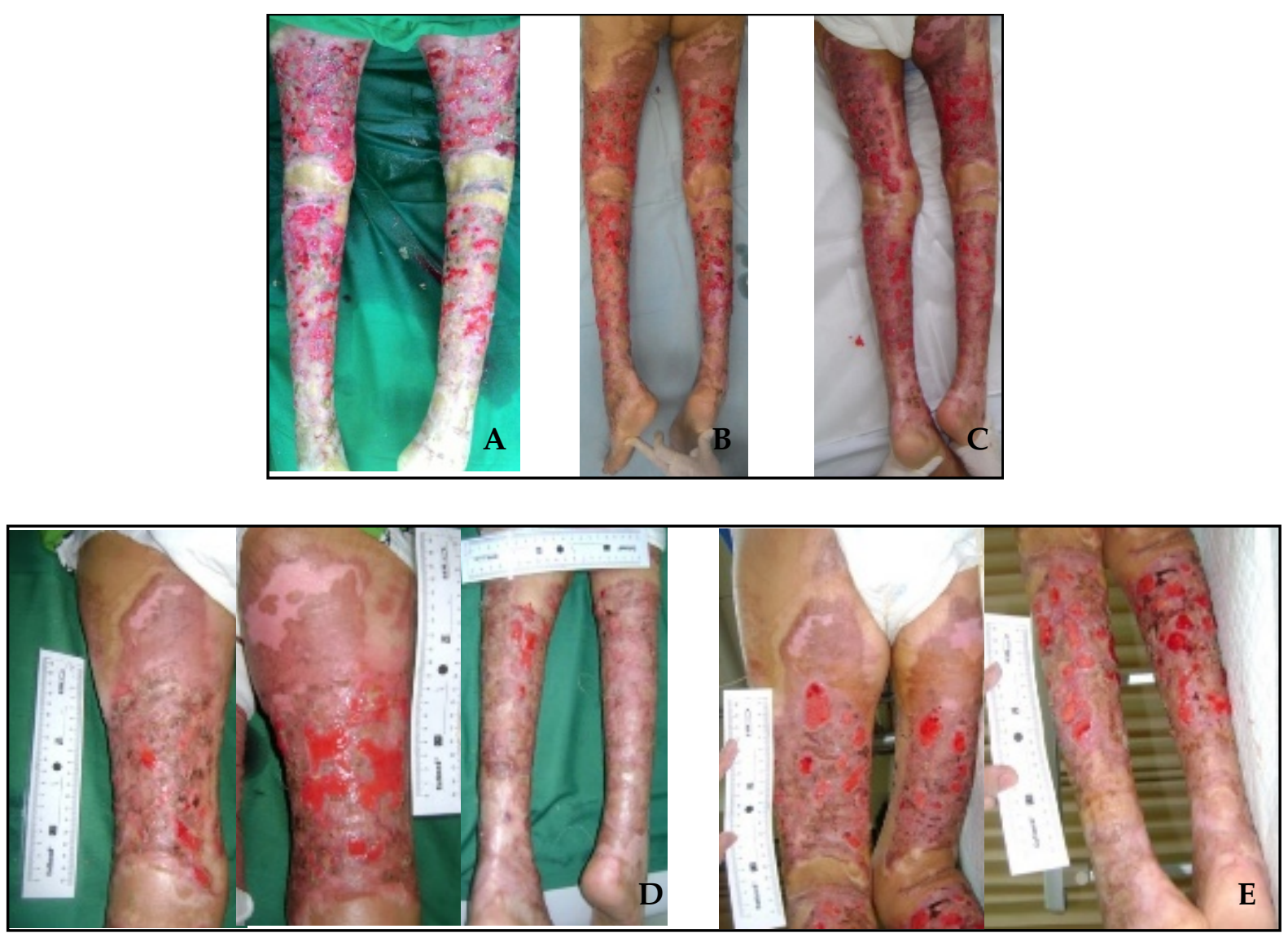

Figure 1. Case 1, 51 years old female: A. Intraoperative 12/12/2014 B. Dressing change 18/12/2014 (H+6) C. Dressing change 03/01/2015 (H+22) D. Dressing change 14/01/2015 (H+33) E. Dressing change 16/03/2015 $(\mathrm{H}+95)$ 
Case 2: 35 years old female. This patient had burn injury grade II and III about 36,5\% total body surface area due to fire. She had inadequate donor to close the defect with skin graft, and we performed mesenchymal stem cells therapy to the wound.
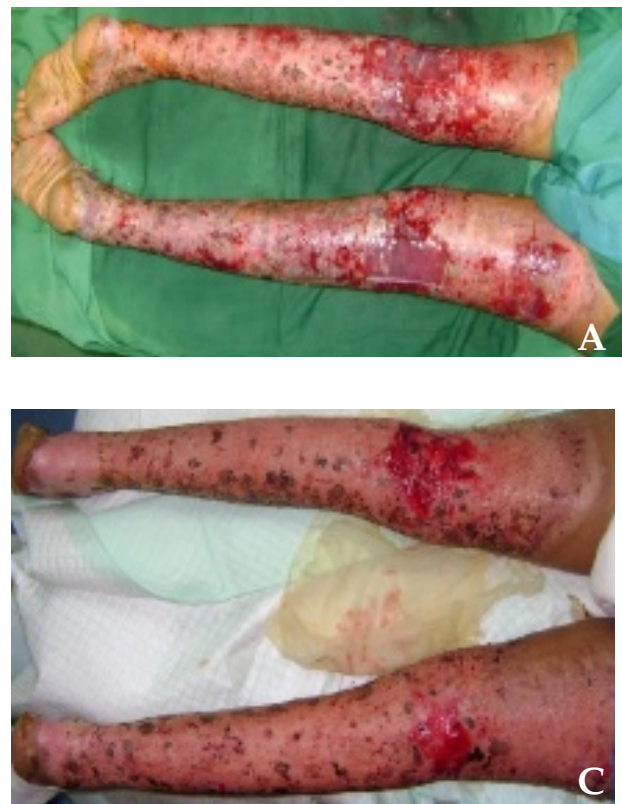

The result observed after therapy was that the advancement of the epithelialization from margin to the raw surface was faster from the other region of the body treated with standard therapy.
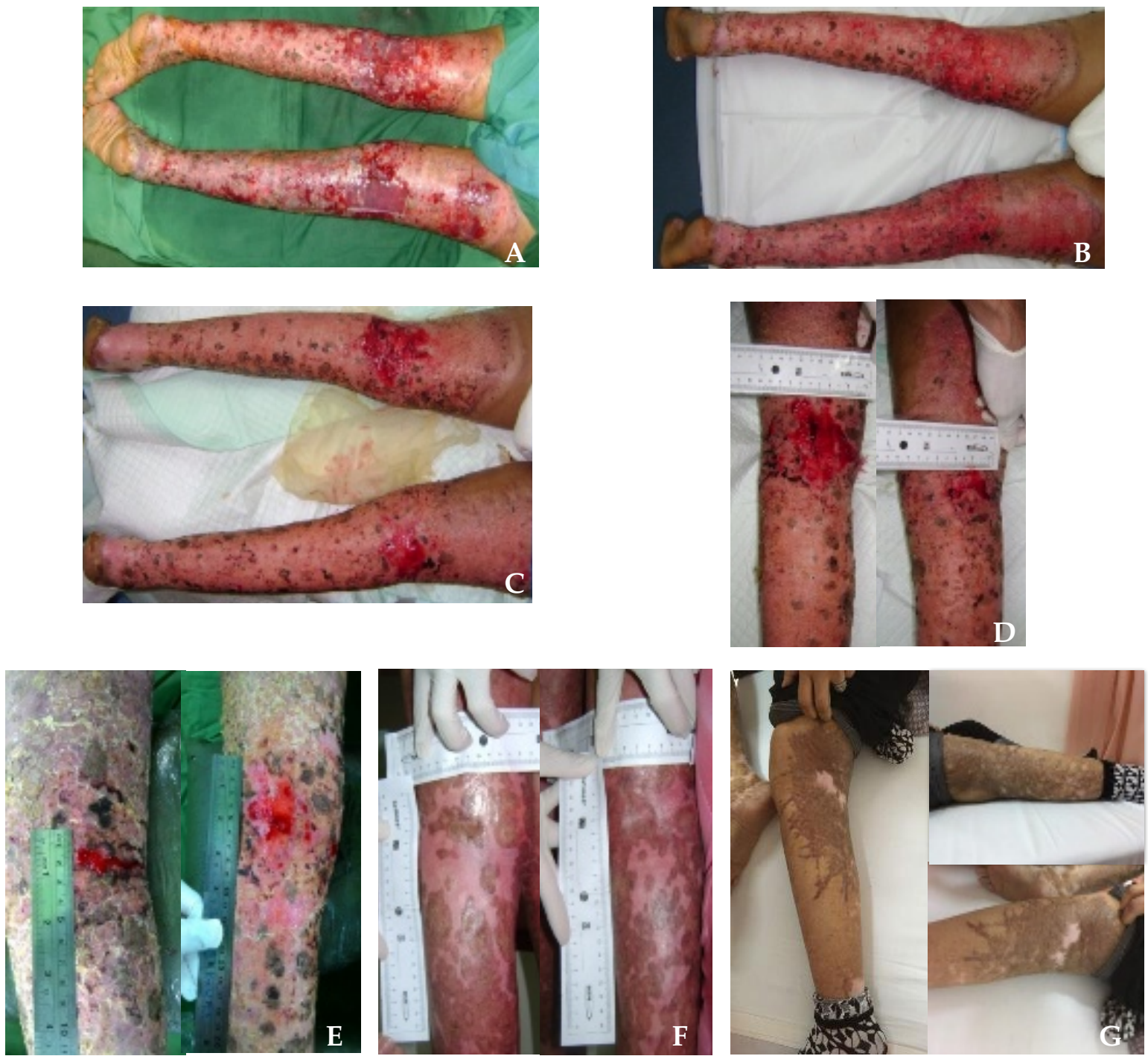

Figure 2. Case 2. 35 years old,woman: A. Intraoperative with procedure MSCs treatment 01/01/15 B. Dressing change 03/01/2015 (H+2) C. Dressing change 09/01/2015 (H+8) D. Dressing change 14/01/2015 $(\mathrm{H}+13)$ E. Dressing change 21/01/2015 (H+20) F. Dressing change 28/02/2015 (H+58) G. After 2 years of MSC application 
Case 3: 13 years old male. He had burn injury grade II and III, about $41,5 \% \%$ total body surface due to fire. This patient also had inadequate donor to close the defect with skin graft, and we also performed mesenchymal stem cells therapy to the wound. The result was the advancement of epithelialization from margin to the raw surface was also faster from the other region of the body treated with standard therapy as observed in case 2.
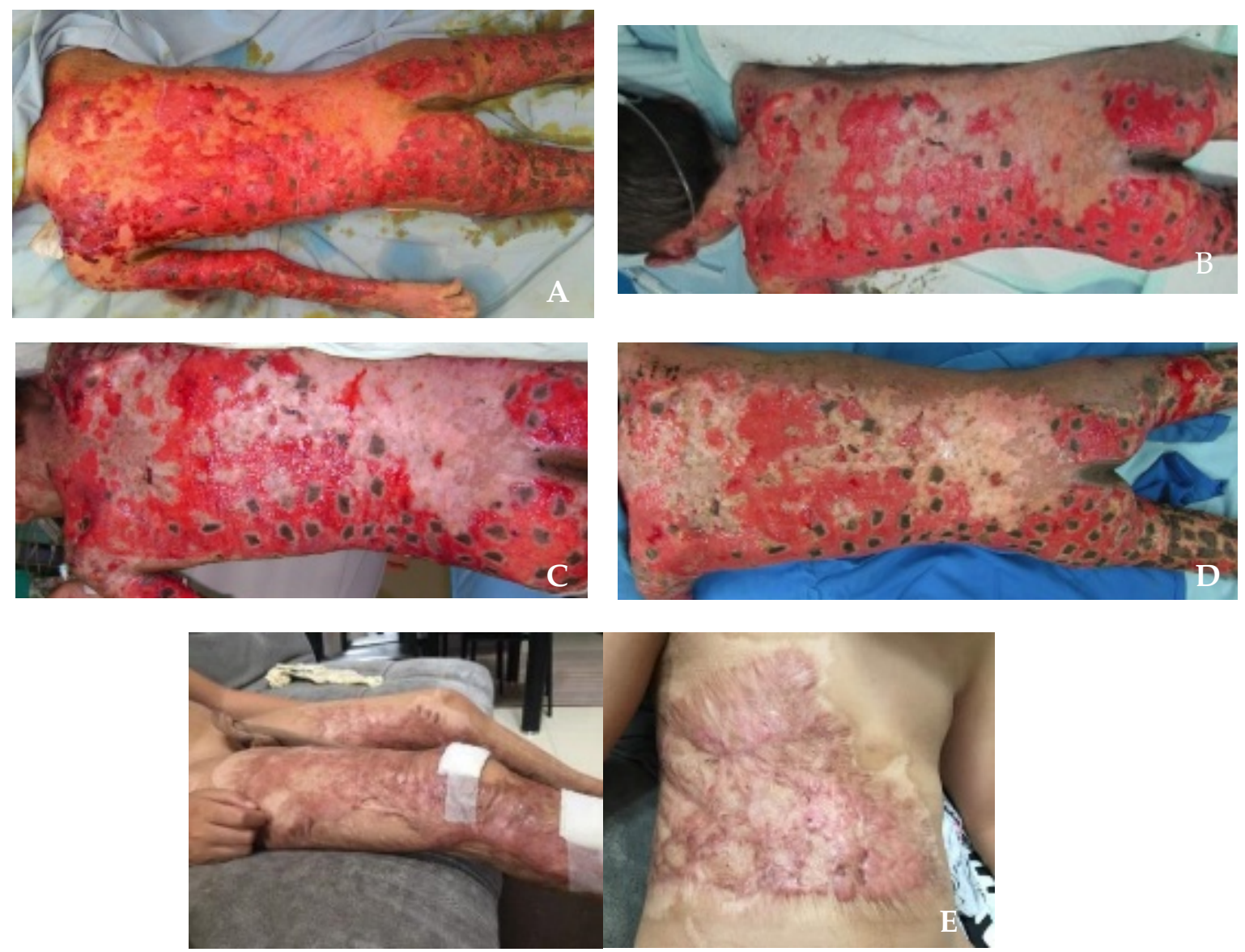

Figure 3: Case 3. A 7 years old boy: A. Intraoperative with procedure MSCs treatment Intraoperation 22/12/14 B. Dressing change 25/12/2014 (H+3) C. Dressing change 03/01/2015 (H+12) D. Dressing change 10/01/2015 (H+19) E. After 2 years of MSC application

\section{DISCUSSION}

Cell therapy has been used to treat burns since the introduction of composite epithelial autografts (CEA) by Green in 1975, evolving to dermal substitutes, later on to dermal-epidermal bio-engineered cultured skin substitutes and eventually to stem cells.(1) Stem cell therapy after burn injury emerges as a promising treatment strategy, not only for wound healing, but also to treat systemic effects of burn trauma, the hyper metabolic response, inflammation (e.g., inflammatory-related diseases, such as acute lung injury/respiratory distress syndrome), and immunosuppression. (2) Stem cell therapy may offer an alternative to large volume resuscitation and be an adjunct to lung-protective ventilation strategies after severe burn injury 3. Paracrine mechanisms and growth factor secretion, rather than post-engraftment differentiation and proliferation, seem to predominate in therapeutic effects of MSCs .(1) In vivo, MSCs attenuate proinflammatory cytokine release and nitric oxide production while upregulating the antiinflammatory cytokines TGF- $\alpha$, IL-10 and IL-12. (4).MSCs also exhibit antiapoptotic, immunosuppressive and anti-fibrotic effects (5). For the treatment of acute and chronic nonhealing wounds (not burn related), combined 
gene delivery with stem cell therapy appears promising (6). Gene therapy involves the insertion of a gene into recipient cells by viral transfection, naked DNA application, high pressure injection or liposomal vectors (7). Sequential growth factor gene therapy delivers a cocktail of growth factor genes at strategic time points of wound healing. (8)

Promising results were revealed in this study, in the form of increased epithelialization rate of the burn wounds after application of MSCs therapy, even in a previously infected wound. However, in follow up, unfavorable scars occurred in 2 patients. Apparently, MSCs couldn't inhibit the occurrence of hypertrophic scar. Further researches are still needed on the role of MSCs in wound healing on the complex burn injury.

\section{CONCLUSION}

This study suggests that MSCs can effectively improve wound healing in severe burns patients. Unfortunately, hypertrophic scars developed in the two patients couldn't be avoided as it is among the common burns complications.

\section{Corresponding author :}

Aditya Wardhana

aditya_wrdn@yahoo.com

\section{REFERENCES}

1. Leclerc, T.; Thepenier, P.J.; Bey, E.; Peltzer, J.; Trouillas, M.; Duhamel, P.; Bargues, L.; Prat, M.; Bonderriter, M.; Lataillade, J.J. Cell therapy of burns. Cell Prolif. 2011. 44, 48-54

2. Butler, K.L.; Goverman, J.; Ma, H.; Fischman, A.; Yu, Y.M.; Bilodeau, M.; Rad, A.M.; Bonab, A.A.; Tompkins, R.G.; Fagan, S.P. Stem cells and burns: Review and therapeutic implications. J. Burn Care Res. 2010, 31, 874-881

3. Dancey, D.R.; Hayes, J.; Gomez, M.; Schouten, D.; Fish, J.; Peters, W.; Slutsky, A.S.; Stewart, T.E. ARDS in patients with thermal injury. Intens. Care Med. 1999, 25, 1231-1236

4. Weil, B.R.; Markel, TA.; Herrmann, J.L.; Abarbanell, A.M.; Kelly, M.L.; Meldrum, D.R. Stem cells in sepsis. Ann. Surg. 2009, 250, 219-227

5. Uccelli, A.; Moretta, L.; Pistoia, V. Mesenchymal stem cells in health and disease. Nat. Rev.Immunol. 2008, 8, 726-736.

6. Branski, L.K.; Gauglitz, G.G.; Herndon, D.N.; Jeschke, M.G. A review of gene and stem cell therapy in cutaneous wound healing. Burns 2009, 35, 171-180.

7. Khavari, P.A.; Rollman, O.; Vahlquist, A. Cutaneous gene transfer for skin and systemic diseases. J. Int. Med. 2002, 252,1-10.

8. Sprugel, K.H.; McPherson, J.M.; Clowes, A.W.; Ross, R. Effects of growth factors in vivo. I Cell ingrowth into porous subcutaneous chambers. Am. J. Pathol. 1987, 129, 601-613. 